\title{
Influence of Intelligent Navigation on Exhibition Identity of Atypical Visitors in Experience Context
}

\begin{abstract}
Wanyun Zhang*
China

*Corresponding Author: Wanyun Zhang, China

Abstract: Under the background of the "Internet plus" era, smart venue services combining artistic tastes and participation in the experience have become an inevitable requirement for venue construction. An atypical visitor is the majority group that cannot be ignored in the exhibition. The intelligent navigation function, as one of the services most closely related to atypical visitors in smart venue services, is a crucial factor that affects the visitor's sense of experience and exhibition identity. Thus, this study takes atypical visitors of the 21st China International Hi-tech Fair as an example and investigates their use of intelligent navigation service, as well as experience and sense of exhibition identification. Meanwhile, the influence of intelligent navigation function on the exhibition identification of atypical visitors in the context of experience is discussed by using the method of literature analysis and empirical research. The results revealed that the intelligent navigation function can enhance the sense of experience of atypical visitors and their sense of exhibition identification, providing practical suggestions for exhibition organizers to enhance the influence of the exhibition.
\end{abstract}

Keywords: intelligent navigation function; atypical visitor; experience value; exhibition identity

\section{INTRODUCTION}

The current practical data show that the vast majority of exhibition visitors include various atypical visitors [1]. Lately, smart venues have become an inevitable development trend of venue construction with the rapid development of information. Meanwhile, the demand for knowledge consumption has been increasing. More people are participating in the exhibition, and the demand for the exhibition experience differs from the past. However, problems of large-scale exhibition venues are complex structure, large passenger flow, and unclear routes [2]. Therefore, an intelligent navigation function that supports the use of mobile phones and provides precise navigation and information exchange services is imperative.

The intelligent navigation combined with high-tech, such as VR/AR, with the assistance of mobile devices, has already provided audiences with a full range of audio-visual services [3]; these services enable the audience to obtain timely and accurate route guidance and interpretation of the exhibition area [4], providing immersive and experiential exhibition experience for the audience and leaving a deep impression of atypical visitors.

The major contents of the intelligent navigation function are knowledge services, navigation services, and interaction services. It is a crucial aspect of atypical visitors' experience, and the sense of experience is connected with the atypical visitors' awareness and recognition of the exhibition. This study aimsto explore whether the application and progress of the intelligent navigation function can improve the visitor's recognition of the exhibition by enhancing the experience value of the audience, thereby increasing the communication and influence of the exhibition.

\section{RESEARCH HYPOTHESES AND DESIGNS}

This study defines experience value as the cognitive value that mobilizes audience emotions, guides audience behavior and psychology, and exertsa positive impact onthe exhibition through multisensory connection and participation. Focusing on the exhibition experience value, this study proposes the following research hypotheses:

H1: Knowledge services exerta significant positive impact on the experience value of atypical 
visitors.

$\mathrm{H} 2$ : Navigation services exerta significant positive impact on the experience value of atypical visitors. H3: interaction services exerta significant positive impact on the experience value of atypical visitors.

By drawing on the five-dimensional model of brand research, this study categorizes exhibition identification into three dimensions - notability, perception quality, and loyalty. Regarding relevant local identity research models, the following research hypotheses are proposed:

H4: The experience value exertsa significant positive impact on the visibility of atypical visitors.

H5: The experience value exertsa significant positive impact on the exhibition perception quality of atypical visitors.

H6: The experience value exertsa significant positive impact on the exhibition loyalty of atypical visitors.

This study was conducted on-site at the Shenzhen Convention and Exhibition Center during the Open Day of the $21^{\text {st }}$ Hi-Tech Fair on November 15-17, 2019. The design of the questionnaire primarily refers to the concepts and items of previous research, including the intelligent navigation function, visitor experience value, and exhibition approval. Overall, 530 questionnaires were distributed on-site, of which 514 valid questionnaires were recovered eventually, with a valid rate of $97 \%$.

\section{RESULTS AND DISCUSSION}

\subsection{Analysis of General Information}

The samples were descriptively analyzed to ensure the recovered samples were used for data analysis. For the background investigation, the proportion of males was marginally higher than that of females, but without much difference between them. No sample bias existed in this study. Males accounted for $48 \%$, whereas females accounted for $52 \%$. Regarding age, the survey samples concentrated in the age group of 18-35 years, of which the 18-25 year age group accounted for 37.5\%, and the 26-35 year age group accounted for $41.2 \%$, suggesting that the overall survey sample was younger. Regarding the education background, the proportion of undergraduates and above accounted for $72.6 \%$, that is, the surveyed samples were generally well-educated.

Regarding the participation of exhibitions, the surveyed samples that participated in $<10$ exhibitions accounted for $77.1 \%$, of which those participating in 1-5 exhibitions accounted for $51.4 \%$ and 5-10 exhibitions accounted for $25.7 \%$, suggesting that the majority of surveyed samples participated in more exhibitions. Regarding the types of samples participating in the survey, the major type was technical communication, accounting for $19.5 \%$, and the remaining proportions were relatively average, suggesting that most of the samples were technology-preferred. Regarding the role of the exhibition, most of the surveyed samples' participation roles were diversified, among which professional and technical personnel, peer practitioners, suppliers, and students/teachers/associations accounted for $19.5 \%, 38.4 \%, 20.6 \%$, and $17.5 \%$, respectively.

\subsection{Correlation Analysis}

The Pearson correlation coefficient indicates the correlation between variables. The higher absolute value of the correlation coefficient suggestsa stronger correlation between the variables; else, the correlation between the variables is weaker. In this study, we used the SPSS 22.0 software to validate the correlation among the intelligent navigation function, experience value, and factors of exhibition recognition (Table 1).

Table1. Correlation analysis of variables

\begin{tabular}{|c|c|c|c|c|c|c|c|c|}
\hline & & $\begin{array}{l}\text { Knowledge } \\
\text { service }\end{array} \mid$ & $\begin{array}{l}\text { Navigation } \\
\text { service }\end{array}$ & $\begin{array}{l}\text { Interaction } \\
\text { service }\end{array}$ & $\begin{array}{l}\text { Experience } \\
\text { value }\end{array}$ & $\begin{array}{l}\text { Exhibition } \\
\text { notability }\end{array}$ & $\begin{array}{l}\text { Exhibition } \\
\text { perception } \\
\text { quality }\end{array}$ & $\begin{array}{l}\text { Exhibition } \\
\text { loyalty }\end{array}$ \\
\hline \multirow{3}{*}{$\begin{array}{l}\text { Knowledge } \\
\text { service }\end{array}$} & Pearson correlation & 1 & & & & & & \\
\hline & $\begin{array}{l}\begin{array}{l}\text { Significance } \\
\text { (bilateral) }\end{array} \\
\end{array}$ & & & & & & & \\
\hline & $N$ & 514 & & & & & & \\
\hline Navigation & Pearson correlation & $0.665 * *$ & 1 & & & & & \\
\hline
\end{tabular}


Influence of Intelligent Navigation on Exhibition Identity of Atypical Visitors in Experience Context

\begin{tabular}{|c|c|c|c|c|c|c|c|c|}
\hline \multirow[t]{2}{*}{ service } & $\begin{array}{l}\text { Significance } \\
\text { (bilateral) }\end{array}$ & 0.000 & & & & & & \\
\hline & $N$ & 514 & 514 & & & & & \\
\hline \multirow{3}{*}{$\begin{array}{l}\text { Interaction } \\
\text { service }\end{array}$} & Pearson correlation & $0.566^{* *}$ & $0.550 * *$ & 1 & & & & \\
\hline & \begin{tabular}{|l|}
$\begin{array}{l}\text { Significance } \\
\text { (bilateral) }\end{array}$ \\
\end{tabular} & 0.000 & 0.000 & & & & & \\
\hline & $N$ & 514 & 514 & 514 & & & & \\
\hline \multirow{3}{*}{$\begin{array}{l}\text { Experience } \\
\text { value }\end{array}$} & Pearson correlation & $0.560 * *$ & $0.530 * *$ & $0.555 * *$ & 1 & & & \\
\hline & $\begin{array}{l}\text { Significance } \\
\text { (bilateral) }\end{array}$ & 0.000 & 0.000 & 0.000 & & & & \\
\hline & $N$ & 514 & 514 & 514 & 514 & & & \\
\hline \multirow{3}{*}{$\begin{array}{l}\text { Exhibition } \\
\text { notability }\end{array}$} & Pearson correlation & $0.543 * *$ & $0.531 * *$ & $0.566 * *$ & $0.560 * *$ & 1 & & \\
\hline & $\begin{array}{l}\text { Significance } \\
\text { (bilateral) }\end{array}$ & 0.000 & 0.000 & 0.000 & 0.000 & & & \\
\hline & $N$ & 514 & 514 & 514 & 514 & 514 & 514 & 514 \\
\hline \multirow{3}{*}{$\begin{array}{l}\text { Exhibition } \\
\text { perception } \\
\text { quality }\end{array}$} & Pearson correlation & $0.472 * *$ & $0.459 * *$ & $0.431 * *$ & $0.528 * *$ & $0.532 * *$ & 1 & \\
\hline & \begin{tabular}{|l|}
$\begin{array}{l}\text { Significance } \\
\text { (bilateral) }\end{array}$ \\
\end{tabular} & 0.000 & 0.000 & 0.000 & 0.000 & 0.000 & & \\
\hline & $N$ & 514 & 514 & 514 & 514 & 514 & 514 & \\
\hline \multirow{3}{*}{$\begin{array}{l}\text { Exhibition } \\
\text { loyalty }\end{array}$} & Pearson correlation & $0.567 * *$ & $0.519 * *$ & $0.559 * *$ & $0.550 * *$ & $0.675 * *$ & $0.589 * *$ & 1 \\
\hline & $\begin{array}{l}\text { Significance } \\
\text { (bilateral) }\end{array}$ & 0.000 & 0.000 & 0.000 & 0.000 & 0.000 & 0.000 & \\
\hline & $N$ & 514 & 514 & 514 & 514 & 514 & 514 & 514 \\
\hline
\end{tabular}

As shown in Table 1, knowledge services moderately and significantly correlated with the experience value, exhibition notability, exhibition perception quality, and exhibition loyalty; navigation services moderately and significantly correlated with the experience value, exhibition notability, exhibition perception quality, and exhibition loyalty; interaction services positively and significantly correlated with the experience value, exhibition notability, exhibition perception quality, and exhibition loyalty; experience value moderately, positively, and significantly correlated with the exhibition notability, exhibition perception quality, and exhibition loyalty.

\subsection{Linear Regression Analysis}

In this study, weappliedthe linear regression equation to analyze the degree of influence between variables. Based on the research model proposed in this study, one multivariate linear regression analysis and four univariate linear regression analyses are required.

Table2. Variable definitions for multiple regression

\begin{tabular}{|c|c|c|}
\hline Variable type & Variable name & Symbols \\
\hline Explained variable & Experience value & EV \\
\hline Explanatory variables & Knowledge service & AKI \\
\hline Explanatory variables & Navigation service & AGI \\
\hline Explanatory variables & Interaction service & AAI \\
\hline
\end{tabular}

Thus, the multiple regression equation of the dependent variable experience value for independent variable knowledge service, navigation service, and interaction service is expressed as follows:

$\mathrm{EV}=\alpha_{0}+\beta_{1} \mathrm{AKI}+\beta_{2} \mathrm{AGI}+\beta_{3} \mathrm{AAI}+\varepsilon$

where $\alpha_{0}$ is the intercept of the regression line; $\beta_{1}, \beta_{2}$, and $\beta_{3}$ are the slopes of the regression line, denoting the changes in the dependent variable when the independent variable changes by one unit; and $\varepsilon$ is the random error of the regression equation.

Table3. Variable definitions for univariate regression

\begin{tabular}{|c|c|c|}
\hline Variable type & Variable name & Symbols \\
\hline Explained variable & Exhibition notability & BA \\
\hline Explained variable & Exhibition perception quality & BPQ \\
\hline Explained variable & Exhibition loyalty & BL \\
\hline Explanatory variables & Experience value & EV \\
\hline
\end{tabular}


Thus, the univariate regression equations of the dependent variable exhibition notability, exhibition perception quality, and exhibition loyalty to the independent variable experience value are expressed as follows:

$$
\begin{aligned}
& \mathrm{BA}=\alpha_{1}+\beta_{4} \mathrm{EV}+\mu_{1} \\
& \mathrm{BPQ}=\alpha_{2}+\beta_{5} \mathrm{EV}+\mu_{2} \\
& \mathrm{BL}=\alpha_{3}+\beta_{6} \mathrm{EV}+\mu_{3}
\end{aligned}
$$

where $\alpha_{1}, \alpha_{2}$, and $\alpha_{3}$ are the intercepts of the regression line; $\beta_{4}, \beta_{5}$, and $\beta_{6}$ are the slopes of the regression line, denoting the changes in the dependent variable when the independent variable changes by one unit; and $\mu_{1}, \mu_{2}$, and $\mu_{3}$ are the random errors of the equations.

By using SPSS 22.0, a stepwise regression analysis method was used to perform a multiple regression analysis on the three factors of the intelligent navigation function and the experience value.

\begin{tabular}{|c|c|c|c|c|c|c|c|c|}
\hline \multirow{2}{*}{\multicolumn{2}{|c|}{ Model }} & \multicolumn{2}{|c|}{ Non-standardized coefficient } & \multirow{2}{*}{ 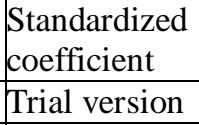 } & \multirow[t]{2}{*}{$t$} & \multirow[t]{2}{*}{ Sig. } & \multicolumn{2}{|c|}{ Collinear statistics } \\
\hline & & $\mathrm{B}$ & Standard deviation & & & & Tolerance & VIF \\
\hline \multirow{4}{*}{1} & (Constant) & 1.521 & 0.139 & & 10.607 & 0.000 & & \\
\hline & Knowledge service & 0.204 & 0.044 & 0.229 & 4.742 & 0.000 & 0.496 & 2.000 \\
\hline & Navigation service & 0.168 & 0.044 & 0.200 & 4.131 & 0.000 & 0.498 & 2.007 \\
\hline & Interaction service & 0.427 & 0.035 & 0.319 & 7.477 & 0.000 & 0.638 & 1.567 \\
\hline
\end{tabular}

Table4. Regression analysis of the influence of intelligent navigation function on the experience value of atypical audience

The experience value model fitted the index, the bias relationship number was 0.684 , the $R^{2}$ value was 0.405 , and the adjusted $R^{2}$ value was 0.403 , that is, the independent variable can explain $40.5 \%$ of the experience value variation. Furthermore, the $F$ value was132.2, and the significance was $<0.01$, that is, extremely significant; thus, the model passed the significance test.

The model can be expressed as follows:

$\mathrm{EV}=1.521+0.204 \times \mathrm{AKI}+0.168 \times \mathrm{AGI}+0.427 \times \mathrm{AAI}$

As shown in Eq.(5), hypotheses 1-3 (H1, H2, and H3) are verified.

By using SPSS 22.0, the regression analysis method was used to perform a univariate regression analysis on the three factors of experience value and exhibition recognition.

\begin{tabular}{|c|c|c|c|c|c|c|c|c|}
\hline \multirow{2}{*}{\multicolumn{2}{|c|}{ Model }} & \multicolumn{2}{|c|}{ Non-standardized coefficient } & \multirow{2}{*}{\begin{tabular}{|l|}
$\begin{array}{l}\text { Standardized } \\
\text { coefficient }\end{array}$ \\
Trial version
\end{tabular}} & & \multirow[t]{2}{*}{ Sig. } & \multicolumn{2}{|c|}{ Collinear statistics } \\
\hline & & $\mathrm{B}$ & Standard deviation & & & & Tolerance & VIF \\
\hline \multirow{2}{*}{1} & (Constant) & 1.312 & 0.141 & & 6.732 & 0.000 & & \\
\hline & Experience value & 0.675 & 0.034 & 0.410 & 15.290 & 0.000 & 1.000 & 1.000 \\
\hline
\end{tabular}

Table5. Regression analysis of the influence of experience value of atypical visitors on the notability of the exhibition

The exhibition notability model fitted the index, the bias relationship number was 0.56 , the $R^{2}$ value was 0.413 , and the adjusted $R^{2}$ value was 0.412 , that is, the independent variable can explain $41.3 \%$ of the experience value variation. Furthermore, the $F$ value was 264.721 , and the significance was $<0.01$, that is, extremely significant; thus, the model passed the significance test.

Regarding the model coefficient, the constant coefficient value was 1.312, the standard error was 0.141 , and the $t$ value was6.732. The significance was $<0.01$, suggesting an extremely significant relationship. The non-standardized coefficient of experience value was 0.673 , the standard deviation was 0.034 , the standardized coefficient was 0.410 , and the $t$ value was 15.290 , which was significantly $<0.01$ and extremely significant. 
Thus, the model can be expressed as follows:

$\mathrm{BA}=1.312+0.675 \times \mathrm{EV}$

Thus, the hypothesis $\mathrm{H} 4$ is verified.

Table6. Regression analysis of the experience value of atypical visitors on the perception quality of the exhibition

\begin{tabular}{|c|c|c|c|c|c|c|c|c|}
\hline \multirow{2}{*}{\multicolumn{2}{|c|}{ Model }} & \multicolumn{2}{|c|}{ Non-standardized coefficient } & \multirow{2}{*}{ 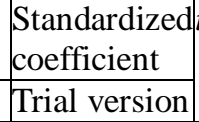 } & & \multirow[t]{2}{*}{ Sig. } & \multicolumn{2}{|c|}{ Collinear statistics } \\
\hline & & B & Standard deviation & & & & Tolerance & VIF \\
\hline & (Constant) & 1.384 & 0.111 & & 14.978 & 0.000 & & \\
\hline & Experience value & 0.521 & 0.035 & 0.528 & 14.070 & 0.000 & 1.000 & 1.000 \\
\hline \multicolumn{9}{|c|}{$R=0.528 ; R^{2}=0.279 ; R^{2}$ is adjusted to $0.277 ; F=254.476^{* *}$} \\
\hline
\end{tabular}

The exhibition perception quality model fitted the index, the bias relationship number was 0.528 , the $R^{2}$ value was 0.279 , and the adjusted $R^{2}$ value was 0.277 , that is, the independent variable can explain $27.9 \%$ of the experience value variation. Furthermore, the $F$ value was 254.476 , and the significance was $<0.01$, that is, extremely significant; thus, the model passed the significance test.

Regarding the model coefficient, the constant coefficient value was 1.384 , the standard error was 0.111 , and the $t$ value was 14.978 . The significance was $<0.01$, suggesting an extremely significant relationship. The non-standardized coefficient of experience value was 0.489 , the standard deviation was 0.035 , the standardized coefficient was 0.528 , and the $t$ value was 14.07 , which was significantly $<0.01$ and extremely significant.

Thus, the model can be expressed as follows:

$\mathrm{BPQ}=1.384+0.521 \times \mathrm{EV}$

Thus, the hypothesis H5 is verified.

Table7. Regression analysis of the experience value of atypical visitors on exhibition loyalty

\begin{tabular}{|c|c|c|c|c|c|c|c|c|}
\hline \multirow{2}{*}{\multicolumn{2}{|c|}{ Model }} & \multicolumn{3}{|c|}{$\begin{array}{c}\text { Non-standardized coefficient } \begin{array}{l}\text { Standardized } \\
\text { coefficient }\end{array} \\
\end{array}$} & & \multirow[t]{2}{*}{ Sig. } & \multicolumn{2}{|c|}{ Collinear statistics } \\
\hline & & $\mathrm{B}$ & Standard deviation & Trial version & & & Tolerance & VIF \\
\hline \multirow{2}{*}{1} & (Constant) & 2.047 & 0.171 & & 7.039 & 0.000 & & \\
\hline & Experience value & 0.535 & 0.042 & 0.520 & 13.919 & 0.000 & 1.000 & 1.000 \\
\hline
\end{tabular}

The exhibition loyalty model fitted the index, the bias relationship number was 0.64 , the $R^{2}$ value was 0.293 , and the adjusted $R^{2}$ value was 0.290 , that is, the independent variable can explain $29.3 \%$ of the experience value variation. The $\mathrm{F}$ value was 261.223 , and the significance was $<0.01$, that is, extremely significant; thus, the model passed the significance test.

Regarding the model coefficient, the constant coefficient value was 1.545 , the standard error was 0.171 , and the $t$ value was7.039. The significance was $<0.01$, indicating an extremely significant relationship. The non-standardized coefficient of experience value was 0.628 , the standard deviation was 0.042 , the standardized coefficient was0.52, and the $t$ value was 13.919 , which is significantly $<0.01$ and extremely significant.

Thus, the model can be expressed as follows:

$\mathrm{BL}=2.047+0.535 \times \mathrm{EV}$

Thus, the hypothesis H6 is verified.

In summary, Table 8 shows the results of this survey.

Table8. Study results

\begin{tabular}{|l|l|l|l|}
\hline $\begin{array}{l}\text { Research } \\
\text { hypotheses }\end{array}$ & Contents & Results \\
\hline H1 & Knowledge services exerta significant positive impact on the & Valid \\
\hline
\end{tabular}




\begin{tabular}{|c|c|c|}
\hline & experience value of atypical visitors. & \\
\hline $\mathrm{H} 2$ & $\begin{array}{l}\text { Navigation services exert a significant positive impact on the } \\
\text { experience value of atypical visitors. }\end{array}$ & Valid \\
\hline $\mathrm{H} 3$ & $\begin{array}{l}\text { Interaction services exert a significant positive impact on the } \\
\text { experience value of atypical visitors. }\end{array}$ & Valid \\
\hline $\mathrm{H} 4$ & $\begin{array}{l}\text { The experience exerts a significant positive impact on the visibility of } \\
\text { atypical visitors. }\end{array}$ & Valid \\
\hline H5 & $\begin{array}{l}\text { The experience exerts a significant positive impact on the exhibition } \\
\text { perception quality of atypical visitors. }\end{array}$ & Valid \\
\hline H6 & $\begin{array}{l}\text { The experience value exerts a significant positive impact on the } \\
\text { exhibition loyalty of atypical visitors. }\end{array}$ & Valid \\
\hline
\end{tabular}

The research results validated all the six research hypotheses proposed in this study. Thus, the knowledge service, navigation service, and interaction service of the intelligent navigation function exerta significant positive impact on the experience value. The experience value exertsa significant positive impact on all dimensions of the exhibition identification, that is, the experience value exerts a significant positive impact on the visibility, perception quality, and loyalty of the exhibition.

\section{CONCLUSION}

Smart service is a crucial means to enhance the experience of atypical visitors. Toconstructsmart venues, efforts should be made to enhance the quality and efficiency of audience services, enhance the interactivity of the platform, and strengthen the visitor's sense of participation and gain. In particular, in the development of intelligent navigation functions, the focus should be on the dissemination of exhibition information and the upgrade of interactive functions. In addition, the mobile terminal service platforms should be well-utilized to provide intelligent services for atypical visitors. This study investigates the impact of the intelligent navigation function on the atypical visitors' exhibition identification in the context of experience, providing ideas and suggestions for the construction of smart venues and the research of atypical visitor participation.

However, as only atypical visitors of the $21^{\text {st }}$ Hi-Tech Fair were selected as survey samples, some limitations could be present in the selection of samples. In addition, the Hi-Tech Fair has already become an iconic exhibition or even a business card for the city; thus, the actual impact of the smart tour on the visitor's recognition of the exhibition could be affected. Thus, to draw more precise and general conclusions, more samples and research on the situation of different types of exhibition visitors are warranted.

\section{REFERENCES}

[1] Athanasios K,Polymeros C. The effects of service brand dimensions on brand loyalty [J].Journal of Retailing and Consumer Services, 2014, 21: 139-147.

[2] Rosson P, Seringhaus F H. Visitor and exhibitor interaction at industrial trade fairs[J]. Journal of Business Research, 1995, 32(1): 81-90.

[3] Wang F, Yan L, Xiong X K, Wu B H. A study on tourist cognition of urban memory in historic sites: acase study of Alley Nanluogu Historic Site in Beijing [J]. Acta Geographica Sinica, 2012, 67(04):545-556.

[4] Brakus J J,Schmitt B H,Zarantonello L.Brand experience: what is it? How is it measured? Does it affect loyalty? [J]. Journal of Marketing, 2009, 73(3): 52-68.

\section{AUTHORS' BIOGRAPHY}

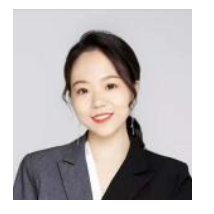

Wanyun Zhang, Shenzhen Tourism College of Jinan University, Shenzhen, China

Citation: Wanyun Zhang. "Influence of Intelligent Navigation on Exhibition Identity of Atypical Visitors in Experience Context" International Journal of Managerial Studies and Research (IJMSR), vol 8, no. 10, 2020, pp. 75-80. doi: https://doi.org/10.20431/2349-0349.0810008.

Copyright: () 2020 Authors. This is an open-access article distributed under the terms of the Creative Commons Attribution License, which permits unrestricted use, distribution, and reproduction in any medium, provided the original author and source are credited. 